\title{
POTENSI PEKARANGAN SEMPIT UNTUK MEMENUHI KEBUTUHAN PANGAN KELUARGA DI PEKANBARU
}

\author{
Surtinah $^{-1}$ \\ Prodi Agroteknologi Fakultas Pertanian Universitas Lancang Kuning \\ Jl. Yos Sudarso Km. 8 Rumbai, Pekanbaru, Riau. \\ e-mail: surtinah@unilak.ac.id
}

\begin{abstract}
ABSTRAK
Tujuan penulisan ini adalah untuk merekomendasikan potensi pekarangan sempit sebagai penghasil pangan keluarga dalam rangka meningkatkan ketahanan pangan dalam keluarga. Metode yang digunakan dalam tulisan ini adalah mereview berbagai hasil penelitian, karya tulis, hasil Pengabdian masyarakat, khususnya yang berhubungan dengan pemanfaatan pekarangan sempit, dan optimalisasi pekarangan sempit. Membandingkan hasil kegiatan dari berbagai sumber dari jurnal penelitian, prosiding dan karya ilmiah yang berhubungan dengan eksploitasi pekarangan sempit. Halaman sempit yang dimiliki dapat diberdayakan untuk menghasilkan tanaman pangan berupa sayur yang dibudidayakan dengan sistem vertikultur. Tanaman yang digunakan untuk budidaya di lahan sempit adalah tanaman yang cepat panen dan memiliki perakaran yang dangkal. Ruang kosong seperti pagar rumah, dan ruang di atas got dapat digunakan untuk budidaya tanaman penghasil sayur, dengan teknik budidaya vertikultur. Sistem budidaya hidroponik yang merujuk pada sistem vertikultur merupakan teknik budidaya yang direkomendasikan untuk memberdayakan pekarangan sempit dan sangat sempit, untuk menghasilkan bahan pangan dalam memenuhi kebutuhan keluarga. Sistem budidaya hidroponik lebih hemat dalam penggunaan air, dan dapat mengatasi kebutuhan akan media tanam tanah yang subur yang sulit diperoleh di Pekanbaru.
\end{abstract}

Kata Kunci : Hidroponik, Pekarangan sempit, Vertikultur,

\section{PENDAHULUAN}

Pekanbaru merupakan kota yang sangat pesat perkembangnnya, pertambahan jumlah penduduk yang pesat dipicu oleh urbanisasi dari Kabupaten, dan banyak yang berasal dari berbagai daerah dari Propinsi yang ada di Indonesia, terutama dari Propinsi Sumatera Utara dan Propinsi Sumatera Barat. Peningkatab jumlah penduduk biasanya akan diikuti dengan peningkatan kebutuhan bahan pangan. Pekanbaru bukanlah kota penghasil komoditi pertanian tanaman pangan, justru untuk memenuhi kebutuhan bahan pangan dari jenis hortikultura Pekanbaru masih banyak mengimpor dari daerah sentra produksi hortikultura seperti Sumatera Barat.

Daerah pertanian di Pekanbaru saat ini sudah berubah menjadi daerah pemukiman, sehingga lahan yang harusnya dapat diberdayakan untuk lahan pertanian, beralih fungsi menjadi lahan pemukiman, kondisi ini semakin mempersempit luasan produksi tanaman pangan. Masalah lain yang dihadapi adalah kondisi tanah yang diplotkan untuk lahan pertanian pada umumnya adalah tanah Podsolik Merah Kuning (PMK) yang sedikit mengandung bahan organik, sedikit 
unsur hara, $\mathrm{pH}$ rendah, sehingga akan menghambat proses budidaya, apabila tanah tersebut tidak diberi tambahan bahan organik.

Lahan pertanian yang sudah berubah fungsi menjadi lahan pemukiman bila dikelola dengan dengan cermat maka akan dapat berdayaguna dan berhasilguna. Daerah-daerah di luar Propinsi Riau seperti di Pulau Jawa keberhasilan memberdayakan pekarangan bisa dijadikan teladan untuk dikembangkan di Pekanbaru. Pemukiman baru yang dibangun pada umumnya memiliki pekarangan yang sempit, dan pekarangan sempit inilah yang menjadi tujuan ekploitasi, sehingga dapat bermanfaat dalam menopang kebutuhan pangan keluarga. Apalagi pada saat ini harga kebutuhan pangan bergerak naik, sehingga bila dapat memanfaatkan halaman yang relatif sempit untuk memenuhi kebutuhan pangannya maka dapat menghemat biaya, juga dapat menghadirkan nuansa estetika, kenyamanan hidup dari polusi udara (Yenisbar dan Rawiniwati, 2012), dan mendapatkan bahan pangan yang segar dan sehat.

Salah satu cara memanfaatkan halaman sempit adalah dengan teknik budidaya vertikultur. Vertikultur adalah sistem tanam di dalam pot/pralon yang disusun/dirakit secara horizontal maupun vertical atau bertingkat pada lahan yang terbatas atau halaman rumah. Kelebihan sistem pertanian hidroponik vertikultur adalah : (1) efisiensi penggunaan lahan, (2) penghematan pemakaian pupuk dan pestisida, (3) kemungkinan tumbuhnya rumput dan gulma lebih kecil, (4) dapat dipindahkan dengan mudah karena tanaman diletakkan dalam wadah tertentu, (5) mempermudah pemeliharaan tanaman. Tanaman yang dapat ditanam dengan teknik vertikultur diusahakan untuk menanam tanaman yang memiliki nilai ekonomis tinggi, berumur pendek, atau tanaman semusim, seperti selada, kangkung, bayam, pokcoy, caisim, tomat, pare, kacang panjang, mentimun, ataupun bunga-bungaan seperti petunia.

Pemanfaatan pekarangan rumah untuk tanaman pangan juga dapat dijadikan sebagai bagian dari gaya hidup (life Style) dalam memenuhi kebutuhan pangan rumah tangga, dengan sikap seperti ini maka kemandirian pangan dalam skala rumah tangga dapat dicapai (Noorsya dan Kustiwan, 2012). Dalam pemanfaatan lahan pekarangan ini yang perlu diperhatikan diantaranya adalah luas lahan pekarangan, pengembangan komoditas dan teknologi pertanian ramah lingkungan serta penyuluhan (Sampellilling, Sitorus, Nurisyah, dan Pramudya, 2012).

Pemberdayaan pekarangan sempit bisa dijadikan sebagai salah satu alternatif menangkal kerawanan pangan dalam keluarga. Kerawanan pangan dapat didefinisikan sebagai kegagalan dalam mencapai ketahanan pangan, baik dalam skala kecil seperti keluarga maupun dalam skala besar seperti Kelurahan, Kecamatan, Kabupaten, Kota, Propinsi, dan Negara. Pola pangan harapan. Pemanfaatan pekarangan sempit dianjurkan menggunakan sistem vertikultur, dan tanaman yang direkomendasikan untuk dibudidayakan adalah tanaman sayur, sedangkan untuk 
pekarangan dengan lahan yang luas direkomendasikan untuk dibudidayakan tanaman sayur, tanaman buah dan tanaman pangan (Nurwati, Surtinah, dan Masykur, 2015).

Peraturan Pemerintah nomor 17 tahun 2015 tentang Ketahanan Pangan dan Gizi adalah kondisi terpenuhinya Pangan bagi negara sampai dengan perseorangan, yang tercermin dari tersedianya Pangan yang cukup, baik jumlah maupun mutunya, aman, beragam, bergizi, merata, dan terjangkau serta tidak bertentangan dengan agama, keyakinan, dan budaya masyarakat, untuk dapat hidup sehat, aktif, dan produktif secara berkelanjutan.

"Kebijakan ketahanan pangan dalam aspek ketersediaan pangan, difokuskan pada peningkatan ketersediaan pangan yang beranekaragam berbasis potensi sumberdaya lokal, dan memantapkan penanganan kerawanan pangan untuk mengurangi jumlah penduduk miskin dan kelaparan" (Darmansyah, 2016).

"Kementrian Pertanian RI melalui Direktorat Jenderal Hortikultura merencanakan Gerakan Perempuan Untuk Optimalisasi Pekarangan (GPOP). Yang menjadi dasar pelaksanaan adalah Peraturan Presiden No. 22 Tahun 2009 tentang Kebijakan Percepatan Penganekaragaman Konsumsi Pangan Berbasis Sumber daya Lokal yang implementasinya adalah pemberdayaan kelompok wanita melalui Optimalisasi Pemanfaatan Lahan Pekarangan”.

Gerakan Percepatan Penganekaragaman Konsumsi Pangan (P2KP) merupakan salah satu upaya untuk mewujudkan peningkatan diversifikasi pangan, sebagai perwujudan dari Peraturan Presiden Nomor 22 Tahun 2009 Tentang Kebijakan Percepatan Penganekaragaman Konsumsi Pangan Berbasis Sumber Daya Lokal, yang ditindaklanjuti oleh Peraturan Menteri Pertanian Nomor 43 Tahun 2009 Tentang Gerakan Percepatan Penganekaragaman Konsumsi Pangan Berbasis Sumber Daya Lokal. P2KP dilaksanakan dalam 3 (tiga) bentuk kegiatan utama yaitu: (a) Optimalisasi Pemanfaatan Pekarangan melalui konsep Kawasan Rumah angan Lestari; (b) Pengembangan Pangan Lokal; serta (c) Promosi dan Sosialisasi P2KP.

Kementerian Pertanian (2011) "menginisiasi optimalisasi pemanfaatan pekarangan melalui konsep Rumah Pangan Lestari (RPL). RPL adalah rumah penduduk yang mengusahakan pekarangan secara intensif untuk dimanfaatkan dengan berbagai sumberdaya lokal secara bijaksana yang menjamin kesinambungan penyediaan bahan pangan rumah tangga yang berkualitas dan beragam. Apabila RPL dikembangkan dalam skala luas, berbasis dusun (kampung), desa, atau wilayah lain yang memungkinkan, penerapan prinsip Rumah Pangan Lestari (RPL) disebut Kawasan Rumah Pangan Lestari (KRPL). Selain itu, KRPL juga mencakup upaya intensifikasi pemanfaatan pagar hidup, jalan desa, dan fasilitas umum lainnya (sekolah, rumah ibadah, dan lainnya), lahan terbuka hijau, serta mengembangkan pengolahan dan pemasaran hasil “. Faktor kunci KPRL akan terwujud, menganekaragamkan pangan, dan 
mengoptimalkan penggunaan pekarangan berbasis sumber daya lokal secara serentak (Saliem, 2011)

Rekomendasi pemanfaatan pekarangan harus berdasarkan program-program yang sudah dilaksanakan seperti diversifikasi pangan dan gizi, gerakan perempuan optimalisasi pekarangan, dan kawasan rumah pangan lestari. Program-program yang direkomendasikan akan terwujud bila masyarakat turut berperan aktif, dan komitmen pemerintah daerah yang kuat (Ashari, Saptana, dan Purwantini, 2012).

Fauzi, Ichniarsyah, dan Agustin (2016), merekomendasikan bahwa dalam memanfaatkan pekarangan diutamakan memanfaatkan sumber daya lokal, menggunakan teknologi sederhana, menggunakan limbah yang ada disekitar lingkungan tinggal, kegiatan dilakukan berkelanjutan tidak hanya insidental, dan perlunya dukungan pemerintah dalam kepastian hukum dan insentif saprodi. Tujuan penulisan ini adalah untuk merekomendasikan potensi pekarangan sempit sebagai penghasil pangan keluarga dalam rangka meningkatkan ketahanan pangan dalam keluarga.

\section{METODE}

Metode yang digunakan dalam tulisan ini adalah mereview berbagai hasil penelitian, karya tulis, hasil Pengabdian masyarakat, khususnya yang berhubungan dengan pemanfaatan pekarangan sempit, dan optimalisasi pekarangan sempit. Membandingkan hasil kegiatan dari berbagai sumber dari jurnal penelitian, prosiding dan karya ilmiah yang berhubungan dengan eksploitasi pekarangan sempit.

\section{HASIL DAN PEMBAHASAN}

Ruang terbuka yang dapat dimanfaatkan di sekitar rumah antara lain; pagar rumah, ruang di atas got, dan halaman rumah.

Pemanfaatan pekarangan sempit untuk menghasilkan tanaman pangan keluarga dilakukan dengan mengoptimalkan penggunaan ruang terbuka yang mendapatkan sinar matahari terutama sinar matahari pagi. Gambar di bawah ini contoh pemanfatan pagar rumah sebagai lahan budidaya sayur, dengan menggunakan wadah talang air, dan media tanam tanah. Hasil yang diperoleh adalah tanaman Pakchoy tumbuh subur dan siap panen. 

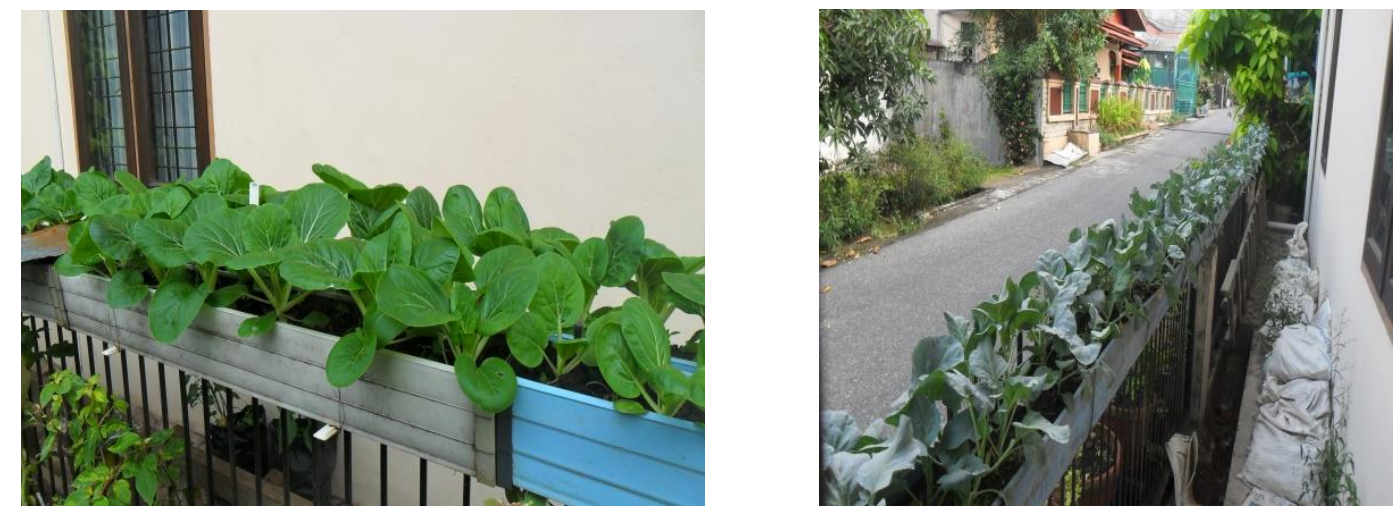

Gambar 1. Pemanfaatan pagar rumah untuk budidaya Pakchoy dan Kailan
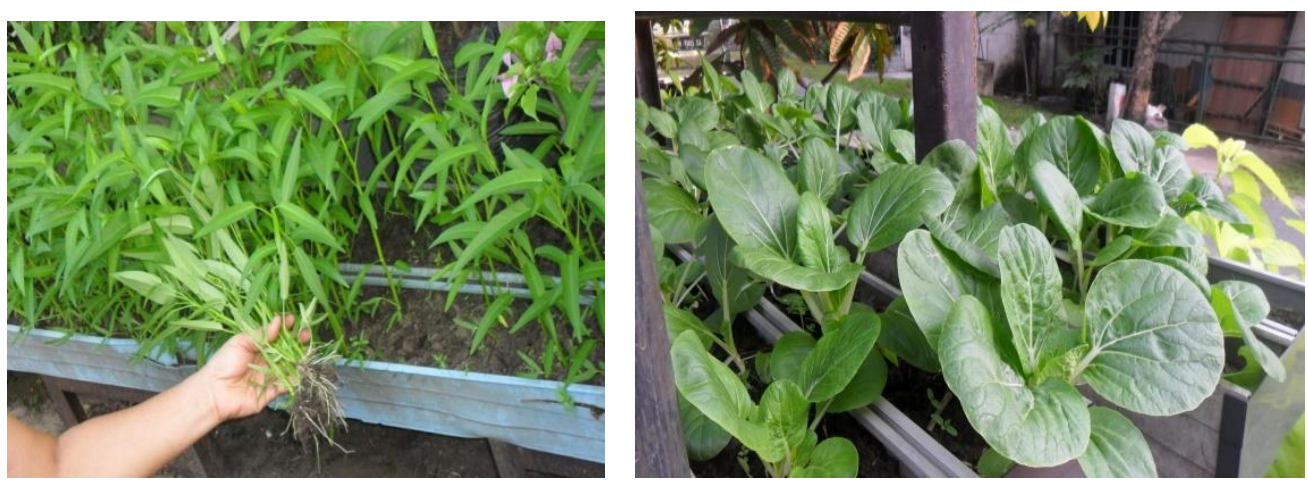

Gambar 2. Pemanfaatan ruang di atas got untuk budidaya kangkung sutera dan Pakchoy

Ruang terbuka yang digunakan pada budidaya sayur seperti gambar di atas, dimana intensitas cahaya matahari cukup diperoleh tanaman dalam menyediakan kebutuhan makan untuk tumbuh dan berkembang, didukung oleh hasil penelitian yang dilaporkan oleh Irwan dan Sarwadi (2016) yang menyatakan bahwa "Ruang sempit dalam permukiman padat menyebabkan tangkapan cahaya untuk pekarangan sangat terbatas, sehingga diperlukan perencanaan pemilihan tanaman yang tahan naungan dan tanaman yang memerlukan pemeliharaan minimal. Alternatif pengembangan pekarangan produktif dengan "tanaman hortikultura dalam pot (tahorlampot)" perlu dipertimbangkan dengan modifikasi desain yang memudahkan pemeliharan dan tangkapan cahaya optimal“.

200 | Potensi Pekarangan Sempit Untuk Memenuhi Kebutuhan Pangan Keluarga Di Pekanbaru 

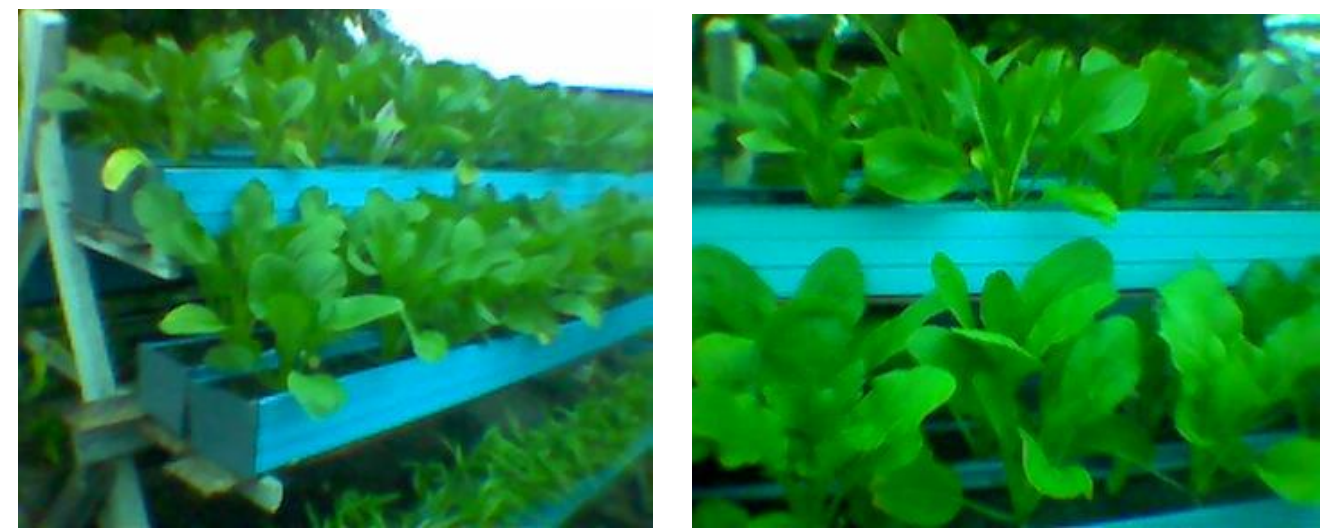

Gambar 3. Sistem vertikultur yang digunakan pada lahan pekarangan sempit

Tanaman sawi varietas cisokan yang ditanam pada media tanam tanah dalam wadah talang air tumbuh subur dan menghasilkan produk agronomi seperti tanaman sawi yang ditanam di lahan terbuka. Hasil ini merupakan hasil penelitian tanaman sawi yang diberi pupuk Plant Catalyst 2006 dengan sistem vertikultur (Surtinah, 2006). Penanaman secara vertikultur dapat menciptakan lingkungan rumah yang produktif sehingga dapat memenuhi kebutuhan pangan dan gizi keluarga di wilayah peri urban kota Semarang (Nurmawati, dan Kadarwati, 2016).

Hasil penelitian yang pernah dilaporkan menyatakan bahwa "keunggulan vertikultur yaitu: hemat lahan, air, pupuk, menerapkan pertanian organik, artinya tidak perlu bahan kimia secara berlebihan, cocok untuk pertanian kota, implementasi pertanian lahan marginal (sempit), meningkatkan produksi keluarga, berperan sebagai sanitasi lingkungan. Tanaman hasil vertikultur lebih cepat untuk dipanen, subur, mudah mengontrol hama, memiliki kandungan hara yang lebih banyak" (Hasyim, dan Mirajuddin, 2013).

Andrianyta, Ulfah, dan Hermawan (2016), melaporkan bahwa pendayagunaan pekarangan orientasi utamanya adalah untuk memenuhi kebutuhan keluarga dan menambah penghasilan keluarga, atau mengurangi pengeluaran belanja keluarga, sehingga budidaya tanaman disekitar rumah dalam Konsep Rumah Pangan Lestari (KRPL) memberikan sumbangsih dalam meningkatkan pendapatan keluarga dan memperkuat ketahanan pangan keluarga.

Kondisi pemanfaatan pekarangan di kota pekanbaru belum maksimal atau belum membudaya, hal ini dilaporkan dari penelitian yang dilakukan oleh Nurwati, Lidar, dan Mufti (2015), bahwa sistem vertikultur yang digunakan di pekarangan sempit menyumbang pendapatan sebesar 72,73\% kurang dari Rp. 1.000.000,- /tahun. Hal ini menunjukkan rendahnya pemanfaatan pekarangan, sumbangan gizi dari produksi pekarangan, rata-rata 1.034.641 kal Kalori, 53.722 gram protein, 17.763 gram lemak, 206.313 gram karbohidrat, 2.135.461 miligram kalium, 1.811.929 miligram phosphor, 24.067 miligram zat besi, 74.545.653 SI Vit A, 3.685 miligram Vit B1 dan 663.915 miligram Vit.C. hal ini menunjukkan bahwa respon masyarakat terhadap RPL masih rendah. hal ini karena adanya faktor sosial-kultur, faktor teknis dan dan faktor ekonomi.

201 | Potensi Pekarangan Sempit Untuk Memenuhi Kebutuhan Pangan Keluarga Di Pekanbaru 
Faktor sosio-kultur dari masyarakat Pekanbaru yang dikenal sebagai masyarakat melayu, kurang suka melakukan proses budidaya atau tidak suka bertani. Faktor lain adalah masyarakat melayu kurang suka mengkonsumsi sayur, hal ini disebabkan pada umumnya masyarakat tinggal di daerah perairan sehingga lebih menyukai bahan pangan yang bersumber dari ikan.

Kondisi seperti ini merupakan suatu kondisi yang akan menghambat tercapainya program ketahanan pangan di tingkat keluarga. Kegiatan yang sudah dilakukan untuk mempercepat tercapainya ketahanan pangan keluarga sudah dilakukan oleh Surtinah, dan Nizar (2017) melalui program pengabdian masyrakat yang orientasinya adalah memanfaatkan teras rumah sebagai sumber pangan keluarga melalui sistem hidroponik sederhana. Program itu hanya bersifat insidental, masyarakat belum terbuka kesadarannya bahwa yang disuluhkan itu adalah sesuatu yang harus dilakukan terus menerus. Kesadaran masyarakat akan pentingnya ketahanan pangan keluarga masih rendah di Pekanbaru, hal ini membuka peluang untuk dilakukan penyuluhan ke seluruh lapisan masyarakat melalui program Pengabdian kepada masyarakat lebih sering lagi, sehingga masyarakat benar benar menyadari akan kepentingan Nasional ini harus dimulai dari keluarga.

Kendala lain dalam budidaya dengan sistem vertikultur, antara lain sulitnya untuk mendapatkan media tanam yang berupa tanah subur. Bila ada maka harganya mahal, sehingga bila dihitung biaya untuk membeli media tanam dengan yang akan dihasilkan tidak sebanding, sebagai alternative dilakukan program pemanfaatan pekarangan sempit dengan sistem budidaya tanaman dengan menggunakan media tanam air. Karena air merupakan bahan cair yang ada di setiap rumahtangga. Teknik budidaya dengan menggunakan air sebagai media tanam dikenal dengan istilah Hidroponik. Hasil produksi hidroponik lebih bagus bila dibandingkan dengan budidaya dengan menggunakan media tanah, karena lebih bersih, dan bisa dijadikan sebagai media pajangan yang bernilai estetika lebih tinggi (Surtinah, dan Nizar, 2017).

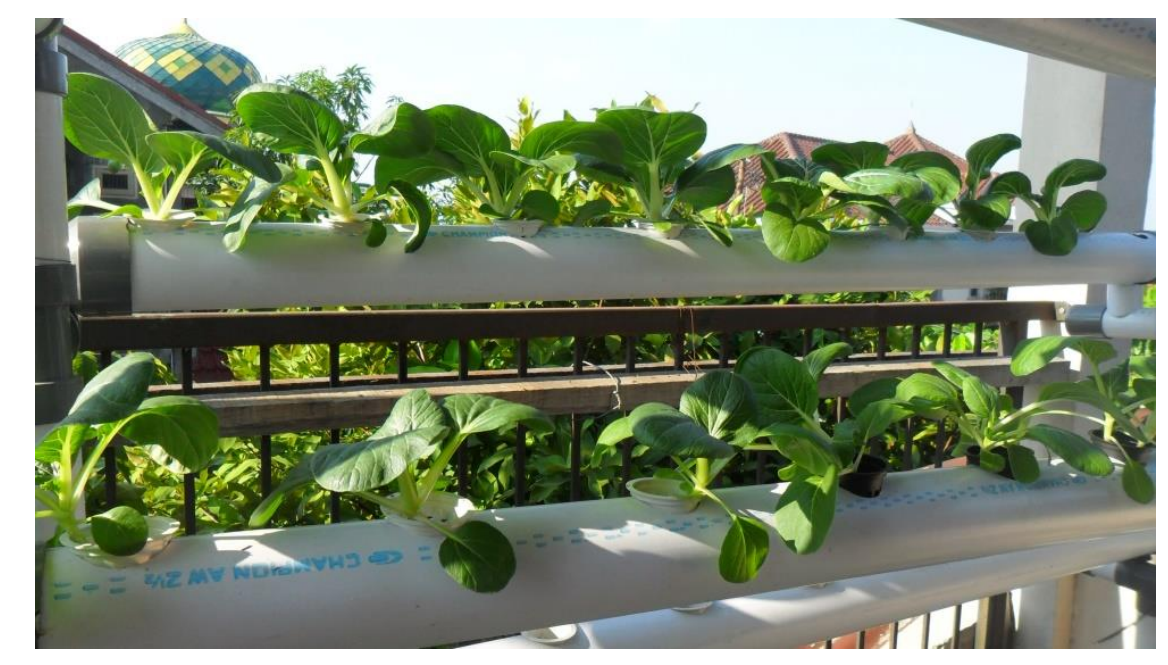

202 Potensi Pekarangan Sempit Untuk Memenuhi Kebutuhan Pangan Keluarga Di Pekanbaru 
Gambar 4. Hasil pakchoy pada system hidroponik di teras rumah
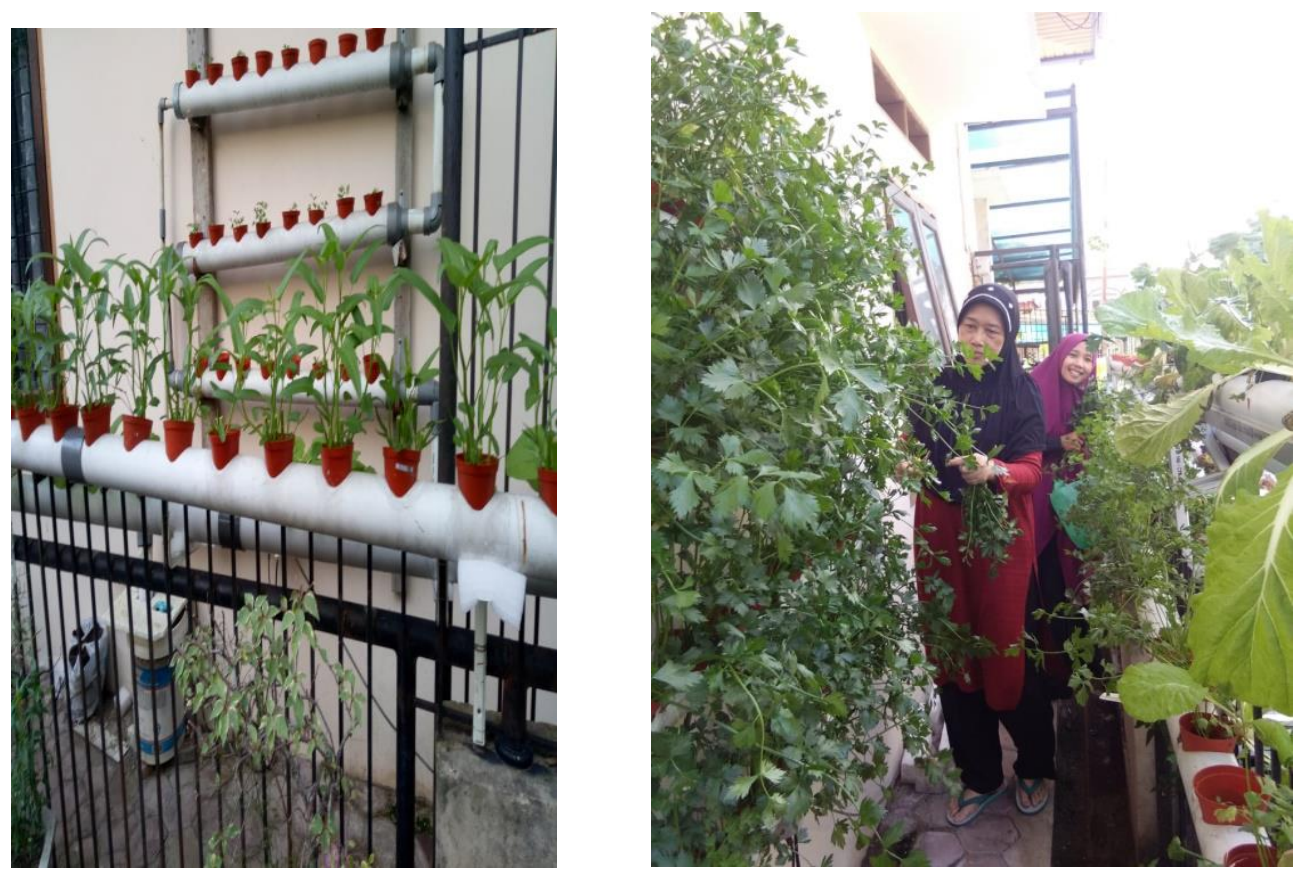

Gambar 5. Dinding rumah yang dimanfaatkan untuk budidaya seledri dengan system hidroponik
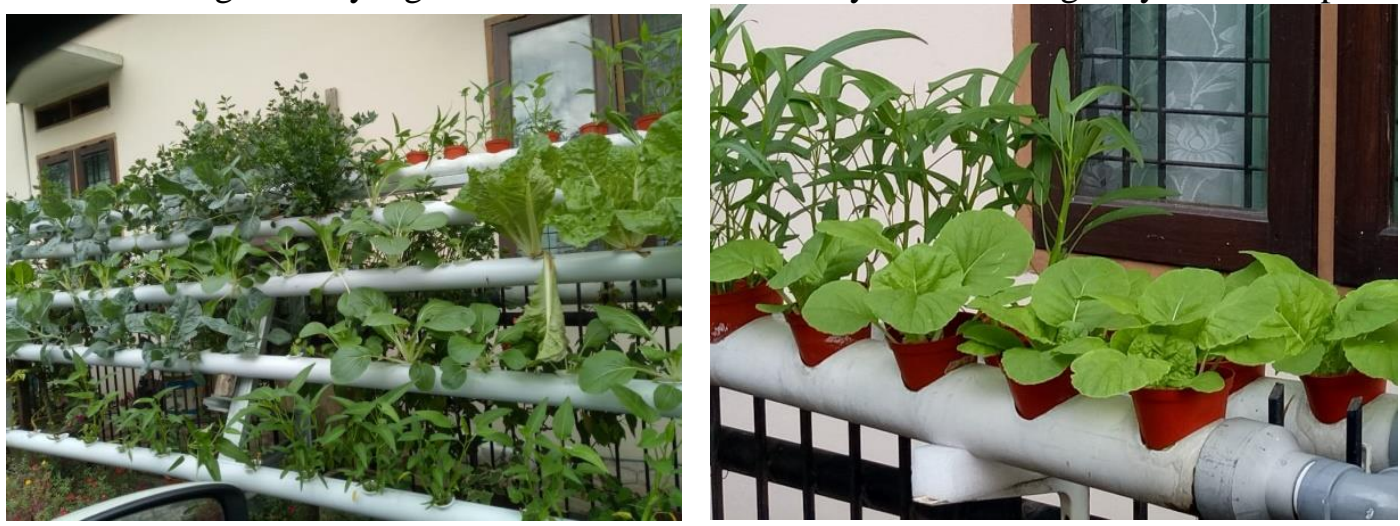

Gambar 6. Pagar rumah yang digunakan untuk budidaya system hidroponik

Hasil penelitian yang dilaporkan oleh Surtinah, dan Lidar (2017), bahwa pakchoy yang ditanam dengan system hidroponik dan diberi zat pengatur tumbuh melalui media tanamnya pertumbuhannya menjadi lebih baik. Budidaya dengan system hidroponik akan lebih baik pertumbuhannya apabila tanaman diberi tambahan zat pengatur tumbuh baik melalui media tanam maupun melalui penyemprotan pada organ daun.

\section{KESIMPULAN}

Halaman sempit yang dimiliki dapat diberdayakan untuk menghasilkan tanaman pangan berupa sayur yang dibudidayakan dengan sistem vertikultur. Tanaman yang digunakan untuk budidaya di lahan sempit adalah tanaman yang cepat panen dan memiliki perakaran yang dangkal. 
Ruang kosong seperti pagar rumah, dan ruang di atas got dapat digunakan untuk budidaya tanaman penghasil sayur, dengan teknik budidaya vertikultur.

Sistem budidaya hidroponik yang merujuk pada sistem vertikultur merupakan teknik budidaya yang direkomendasikan untuk memberdayakan pekarangan sempit dan sangat sempit, untuk menghasilkan bahan pangan dalam memenuhi kebutuhan keluarga. Sistem budidaya hidroponik lebih hemat dalam penggunaan air, dan dapat mengatasi kebutuhan akan media tanam tanah yang subur yang sulit diperoleh di Pekanbaru.

\section{DAFTAR PUSTAKA}

Andrianyta, H., Ulfah, A., dan Hermawan, H., 2016. Dampak Pemanfaatan Pekarangan dalam Perspektif Sosial dan Ekonomi di Kalimantan Timur. Prosiding Seminar Nasional Inovasi Teknologi Pertanian Banjarbaru. Kalimantan.: 1707-1717.

Ashari, Saptana, dan Purwantini, T. B., 2012. Potensi dan Propek Pemanfaatan Lahan Pekarangan untuk Mendukung Ketahanan Pangan. J. Forum Peneitian Agro Ekonomi, Vol. 30 (1): 13-30.

Darmansyah, 2016. Pembangunan Katahan Pangan. Media Informasi Digital. Utusan Riau. CO. http://m.utusanriau.co/index.php?/det/27315; 1 September 2018.

Fauzi, A. R., Ichniarsyah, A. N., dan Agustin, H., 2016). Pertanian Perkotaan: Urgensi, Peranan, Dan Praktik Terbaik. J. Agroteknologi, Vol. 10(1): 49-61.

Hasim, M., Mirajuddin, M., 2013. Pendampingan Pembuatan Media Veltikultur Untuk Penanaman Tumbuhan Obat Dalam Pemaksimalan Pekarangan Rumah. J. Inovasi dan Kewirausahaan, Vol. 2(2): 82-87.

Irwan, S. N. R., dan Sarwadi, 2016. Pemanfaatan Ruang Terbatas Sekitar Rumah Di Permukiman Perkotaan Melalui Pengembangan Lanskap Produktif. Seminar Nasional Sains dan Teknologi. Fakultas Teknik Universitas Muhammadiyah Jakarta . Jakarta.

Kementerian Pertanian. 2011. Pedoman Umum Model Kawasan Rumah Pangan Lestari. Jakarta

Noorsya, A. O., \& Iwan Kustiwan. (2012). Potensi Pengembangan Pertanian Perkotaan untuk Mewujudkan Kawasan Perkotaan Bandung yang Berkelanjutan. Bandung.

Nurmawati, dan Kadarwati, S., 2016. Vertikultur Media Pralon Sebagai Upaya Memenuhi Kemandirian Pangan Di Wilayah Peri Urban Kota Semarang. J. Pendidikan Sains Universitas Muhammadiyah Semarang, Vol. 4(2): 19-25.

Nurwati, N., Lidar, S., dan Mufti. 2015. Model Pemberdayaan Pekarangan Di Kecamatan Rumbai Pesisir Kota Pekanbaru. J. Agribisnis, Vol. 17(1):

Nurwati, N., Surtinah,dan Masykur, A. (2015). ANALISIS PEMANFAATAN PEKARANGAN UNTUK MENDUKUNG KETAHANAN PANGAN DI KECAMATAN RUMBAI PESISIR KOTA PEKANBARU. Jurnal Ilmiah Pertanian, 11(2), 1-8. 
Saliem, H.P., 2011. Kawasan Rumah Pangan Lestari (KRPL): Sebagai Solusi Pemantapan Ketahanan Pangan. Kongres Ilmu Pengetahuan Nasional (KIPNAS), di Jakarta tanggal 810 November 2011

Sampellilling, S., Sitorus, S. R. P., Nurisyah, S., \& Pramudya, B. (2012). Pengembangan Pertanian Kota Berkelanjutan Studi Kasus di DKI Jakarta. J. Analisis Kebijakan Pertanian, 10(3), 257-267.

SURTINAH, S. (2006). PERANAN PLANT CATALYST 2006 DALAM MENINGKATKAN PRODUKSI SAWI (Brassica juncea, L). Jurnal Ilmiah Pertanian, 3(1), 6-16.

Surtinah, S., \& Nizar, R. (2017). PEMANFATAN PEKARANGAN SEMPIT DENGAN HIDROPONIK SEDERHANA DI PEKANBARU. JURNAL PENGABDIAN KEPADA MASYARAKAT, 23(2), 274-278.

Surtinah, S., \& Lidar, S. (2017). Zat Pengatur Tumbuh dalam Nutrisi Hidroponik pada Pertumbuhan dan Hasil Tanaman Pakchoy (Brassica rapa). Jurnal Penelitian Pertanian Terapan, 17(3), 182-185.

Yenisbar, \& Wayan Rawiniwati. (2012). Pengembangan Budidaya Sayuran dengan Sistem Pertanian Vertikultur di Perkotaan. www.google.com. diakses tgl 27 Maret 2017. 